\title{
Enhanced detection of RNA from paraffin- embedded tissue using a panel of truncated gene-specific primers for reverse transcription
}

\author{
Kaidi Mikhitarian ${ }^{1}$, Steve Reott ${ }^{2}$, Loretta Hoover ${ }^{1}$, Ann Allen ${ }^{2}$, David J. \\ Cole ${ }^{1}$, William E. Gillanders ${ }^{1}$, and Michael Mitas ${ }^{1}$ \\ ${ }^{1}$ Medical University of South Carolina, Charleston, SC and ${ }^{2}$ BRT Laboratories, \\ Baltimore, MD, USA
}

BioTechniques 36:474-478 (March 2004)

Formalin-fixed, paraffin-embedded tissues (PET) are a unique source of research material with the potential of providing biological information in conjunction with known clinical outcome. Specifically, these tissues could be an ideal resource for validating newly discovered genes as diagnostic and/or prognostic molecular markers in retrospective studies. Unfortunately, RNA isolated from PET samples is considered to be a poor material for molecular analyses, since RNA is frequently degraded to 100 - to 200-bp fragments by endogenous and exogenous ribonucleases (RNase) (1). In addition, Masuda et al. have shown that RNA, and in particular the poly(A) tail of messenger RNA (mRNA), is chemically modified, making it a poor template for cDNA synthesis (2).

Despite the technical obstacles in the analysis of PET samples, significant improvements have been made in recent years, and various studies have shown that PET samples can be used for reverse transcription PCR (RT-PCR) analysis. The introduction of real-time RT-PCR has helped to overcome some of the difficulties of analyzing degraded RNA due to the fact that this technology has been optimized for the sensitive amplification and detection of short gene fragments $(1,3,4)$. The results obtained from PET sample analysis are highly dependent on the efficiency of reverse transcription. Depending on the quality of RNA, two priming methods are commonly used in cDNA synthesis: (i) oligo(dT) primers, and (ii) random hexamers. Oligo $(\mathrm{dT})$ primers anneal to the poly(A) tail of mRNA. Although this method is preferred with high quality RNA, some studies have also used it for PET analysis $(2,5)$. In the case of degraded mRNA, where the poly(A) tail is often fragmented and/or chemically modified (PET samples), the use of random hexamers is preferred $(1,4,6)$. The major limitation of priming with random hexamers is that any RNA template, not just mRNA, can be primed.

There is a third and less frequently used priming method that relies on gene-specific primers. Gene-specific reverse transcription is used to increase the specificity of the cDNA synthesis and/or enhance the detection level of low abundance RNA transcripts. Although studies have shown that gene-specific reverse transcription can increase the signal detection for a single gene $(7,8)$, the use of multiple gene-specific primers in a single reaction has been problematic due to the presumed formation of primer-dimers that interfere with the reverse transcription and/or subsequent PCR (9).

In an effort to preserve the enhanced nature of signal detection of gene-specific priming and prevent primer-dimer formation, we designed short (truncated) primers (12-14 nucleotides in length) that corresponded to the $5^{\prime}$ end of the reverse primer used for PCR (Table 1). The annealing temperatures for the resulting primers are $40^{\circ}-42^{\circ} \mathrm{C}$, a range that allows the primers to hybridize to their specific template in the reverse transcription reaction, but not during PCR.

In the present study, we hypothesized that the use of a panel of truncated gene-specific primers during reverse transcription is superior to the use of random hexamers, ultimately resulting in significant enhancement of gene fragment detection from PET samples containing highly degraded RNA. To test our hypothesis, we first isolated RNA from 20-, 40-, 60-, and 80- $\mu \mathrm{m}$ sections of formalin-fixed, paraffinembedded breast $(n=2)$, colon $(n=1)$, and lung $(n=1)$ cancer tissues following the method of Stanta and Schneider (7) with some modifications. Briefly, PET sections were deparaffinized twice with $1 \mathrm{~mL}$ of xylene at $37^{\circ} \mathrm{C}$ for $20 \mathrm{~min}$. The pellet was washed with $0.5 \mathrm{~mL}$ of $100 \%$ ethanol $\left(\right.$ at $\left.4{ }^{\circ} \mathrm{C}\right)$ and air-dried at room temperature. The pellet was resuspended in $140 \mu \mathrm{L}$ of prechilled RNA lysis/isolation buffer (1 M guanidine thiocyanate, $0.5 \%$ sarkosyl, 20 mM Tris-HCl, pH 7.5, 25 mM 2-mercaptoethanol) and $60 \mu \mathrm{L}$ of $20 \mathrm{mg} / \mathrm{mL}$ proteinase $\mathrm{K}$ and incubated at $45^{\circ} \mathrm{C}$ for $1 \mathrm{~h}$. RNA was extracted using an equal volume of phenol/chloroform/isoamyl (125:24:1) solution (Sigma, St. Louis, MO, USA). The aqueous layer containing RNA was transferred to a new $1.5-\mathrm{mL}$ tube. After addition of $2 \mu \mathrm{g}$ of glycogen and one volume of isopropanol, precipitation was performed at $-80^{\circ} \mathrm{C}$ for $1-2 \mathrm{~h}$. After centrifugation at $11,760 \times g$ for $30 \mathrm{~min}$ at $4^{\circ} \mathrm{C}$, the RNA pellet was washed with $70 \%$ of ethanol and air-dried at room temperature. Finally, the pellet was dissolved in $50 \mu \mathrm{L}$ of diethylpyrocarbonate (DEPC)-water and stored at $-20^{\circ} \mathrm{C}$. RNA was quantified by spectrophotometry at $260 \mathrm{~nm}$.

In reverse transcription reactions, cDNA was made from $5 \mu \mathrm{g}$ of total RNA using either $150 \mathrm{ng}$ of random hexamers or $500 \mathrm{ng}$ of a panel of truncated gene-specific primers [breast cancer panel: $\beta 2$-microglobin $(\beta 2 m)$, mammaglobin ( $\mathrm{mam}$ ), prolactin-inducible protein $(P I P)$, epithelial cell adhesion molecule $(K S 1 / 4)$, prostate-specific Ets factor $(P S E)$, carcinoembryonic antigen $(C E A)$; lung and colon cancer panel: $\beta 2 m, C E A$, cytokeratin 19 (CK19), mucin 1 ( $m u c l$ ), lung-specific X protein (lunx), KS1/4] (see Table 1). RNA was reverse-transcribed with $200 \mathrm{U}$ of Moloney murine leukemia virus (M-MLV) reverse transcriptase (Promega, Madison, WI, USA) in a reaction volume of $20 \mu \mathrm{L}\left(10 \mathrm{~min}\right.$ at $70^{\circ} \mathrm{C}, 50 \mathrm{~min}$ at $42^{\circ} \mathrm{C}$, $15 \mathrm{~min}$ at $70^{\circ} \mathrm{C}$ ).

Real-time RT-PCR analyses were performed on a GeneAmp ${ }^{\circledR} 5700 \mathrm{Se}$ quence Detection System (Applied Biosystems, Foster City, CA, USA). The 
Table 1. Primers for Gene-Specific Reverse Transcription and Real-Time PCR

\begin{tabular}{|c|c|c|c|c|}
\hline Gene & Sequence of Selected Primer Paira & Reference & $\mathrm{AE}$ & $\begin{array}{l}\text { Intron(s) } \\
\text { Size } \\
\text { (bp) }\end{array}$ \\
\hline$\beta 2 m$ & $\begin{array}{l}\text { F 5'-GCCGTGTGAACCATGTGACTTT-3' } \\
\text { R 5'-CCAAATGCGGCATCTTCAAA-3' }\end{array}$ & 10 & 0.9 & $\begin{array}{c}626 \\
1246\end{array}$ \\
\hline mam & $\begin{array}{l}\text { F 5'-CGGATGAAACTCTGAGCAATGT-3' } \\
\text { R 5'-CTGCAGTTCTGTGAGCCAAAG-3' }\end{array}$ & 11 & 1.0 & 1887 \\
\hline$P I P$ & $\begin{array}{l}\text { F 5'-GCCAACAAAGCTCAGGACAAC-3' } \\
\text { R 5'-GCAGTGACTTCGTCATTTGGAC-3' }\end{array}$ & 11 & 1.0 & 2974 \\
\hline$K S 1 / 4$ & $\begin{array}{l}\text { F 5'-CGCAGCTCAGGAAGAATGTG-3' } \\
\text { R 5'-TGAAGTACACTGGCATTGACGA-3' }\end{array}$ & 12 & 1.0 & 3879 \\
\hline PSE & $\begin{array}{l}\text { F 5'-AGTGCTCAAGGACATCGAGACG-3' } \\
\text { R 5'-AGCCACTTCTGCACATTGCTG-3' }\end{array}$ & 13 & 1.0 & 2835 \\
\hline CEA & $\begin{array}{l}\text { F 5'-GGGCCACTGTCGCATCATGATTGG-3' } \\
\text { R 5'-TGTAGCTGTTGCAAATGCTTTAAGA- } \\
\text { AGAAGC-3' }\end{array}$ & 12 & 1.0 & 1831 \\
\hline muc1 & $\begin{array}{l}\text { F 5'-ACCATCCTATGAGCGAGTACCC-3' } \\
\text { R 5'-GCCACCATTACCTGCAGAAAC-3' }\end{array}$ & 11,12 & 1.0 & 1012 \\
\hline CK19 & $\begin{array}{l}\text { F 5'-CATGAAAGCTGCCTTGGAAGA-3' } \\
\text { R 5'-TGATTCTGCCGCTCACTATCAG-3' }\end{array}$ & 11,12 & 0.65 & 144 \\
\hline $\operatorname{lun} x$ & $\begin{array}{l}\text { F 5'-CCCTGGAAGCCTGCAAATT-3' } \\
\text { R 5'-GAACCAACTCAGGCAGGACTTT-3' }\end{array}$ & 12,14 & 1.0 & 998 \\
\hline \multicolumn{5}{|c|}{$\begin{array}{l}\beta 2 m, \beta 2-\text { microglobin; mam, mammaglobin; } P I P \text {, prolactin-inducible protein; } K S 1 / 4 \text {, epithelial cell adhe- } \\
\text { sion molecule; } P S E \text {, prostate-specific Ets factor; } C E A \text {, carcinoembryonic antigen; muc1, mucin } 1 ; C K 19 \text {, } \\
\text { cytokeratin 19; lunx, lung-specific X protein; F, forward primer; R, reverse primer; AE, amplification ef- } \\
\text { ficiency. } \\
\text { aTruncated gene-specific primers for reverse transcription (bolded sequences) correspond to the } 5^{\prime} \text { end of } \\
\text { reverse primers designed for PCR. }\end{array}$} \\
\hline
\end{tabular}

standard reaction volume was $10 \mu \mathrm{L}$ and contained $1 \times$ QuantiTect $^{\circledR}$ SYBR $^{\circledR}$ Green PCR Master Mix (Qiagen, Valencia, CA, USA), 0.1 U AmpErase ${ }^{\circledR} \mathrm{UNG}$ enzyme (Applied Biosystems), $0.7 \mu \mathrm{L}$ cDNA template, and $0.25 \mu \mathrm{M}$ of both forward and reverse primer. All primers were designed to be intron-spanning to preclude amplification of genomic DNA (Table 1). $\beta 2 m$ was used as an internal control. The initial step of PCR was 2 min at $50^{\circ} \mathrm{C}$ for AmpErase UNG activation, followed by a $15 \mathrm{~min}$ hold at $95^{\circ} \mathrm{C}$. Cycles $(n=40)$ consisted of a 15 -s denaturation step at $95^{\circ} \mathrm{C}$, followed by a 1 min annealing/extension step at $60^{\circ} \mathrm{C}$. The final step was a 1-min incubation at $60^{\circ} \mathrm{C}$. All reactions were performed in triplicate. Real-time RT-PCR data were quantified in terms of cycle threshold $\left(C_{t}\right)$ values. $C_{t}$ values are inversely related to the amount of starting template: high $C_{t}$ values correlate with low levels of gene expression, whereas low $\mathrm{C}_{t}$ values correlate with high levels of gene expression. The specificity of the PCR products was confirmed by dissociation profile analyses, agarose gel electrophoresis, and DNA sequencing (latter two only in initial experiments) (data not shown). The fold difference in signal detection was calculated using the formula $(1+\mathrm{AE})^{\Delta \mathrm{Ct}}$, where $\mathrm{AE}$ is amplification efficiency (Table 1) and $\Delta \mathrm{C}_{\mathrm{t}}=\mathrm{C}_{\mathrm{t}}$ random hexamers $-\mathrm{C}_{\mathrm{t} \text { gene-specific primers }}$.

A representative experiment with $80-\mu \mathrm{m}$ sections of formalin-fixed, paraffin-embedded breast, colon, and lung cancer tissues is shown in Figure 1. Overall, gene-specific priming for all samples analyzed (20-, 40-, 60-, and $80-\mu \mathrm{m}$ sections of four cancer tissues) resulted in an average of 16 ( \pm 5.2$)$-fold increase compared to priming with random hexamers. On a per gene basis, the most significant increase was seen in $m u c l$, where the gene expression signal increased an average of $6.04 \mathrm{C}_{\mathrm{t}} \mathrm{U}$ (66fold). $\beta 2 m$, mam, PIP, and KS1/4 signals increased an average of 4.37 to $5.35 \mathrm{C}_{\mathrm{t}}$ $\mathrm{U}$ (17- to 41-fold). The smallest increase was seen in PSE, CEA, and CK19 signals with an average of $3.17,2.32$, and $0.57 \mathrm{C}_{\mathrm{t}} \mathrm{U}$ (9-, 5-, and 1.3-fold) increase, respectively. Of particular note, we observed that some of the gene expression signals, which were undetectable $\left(C_{t}=\right.$ 40) using random hexamers, were de- 


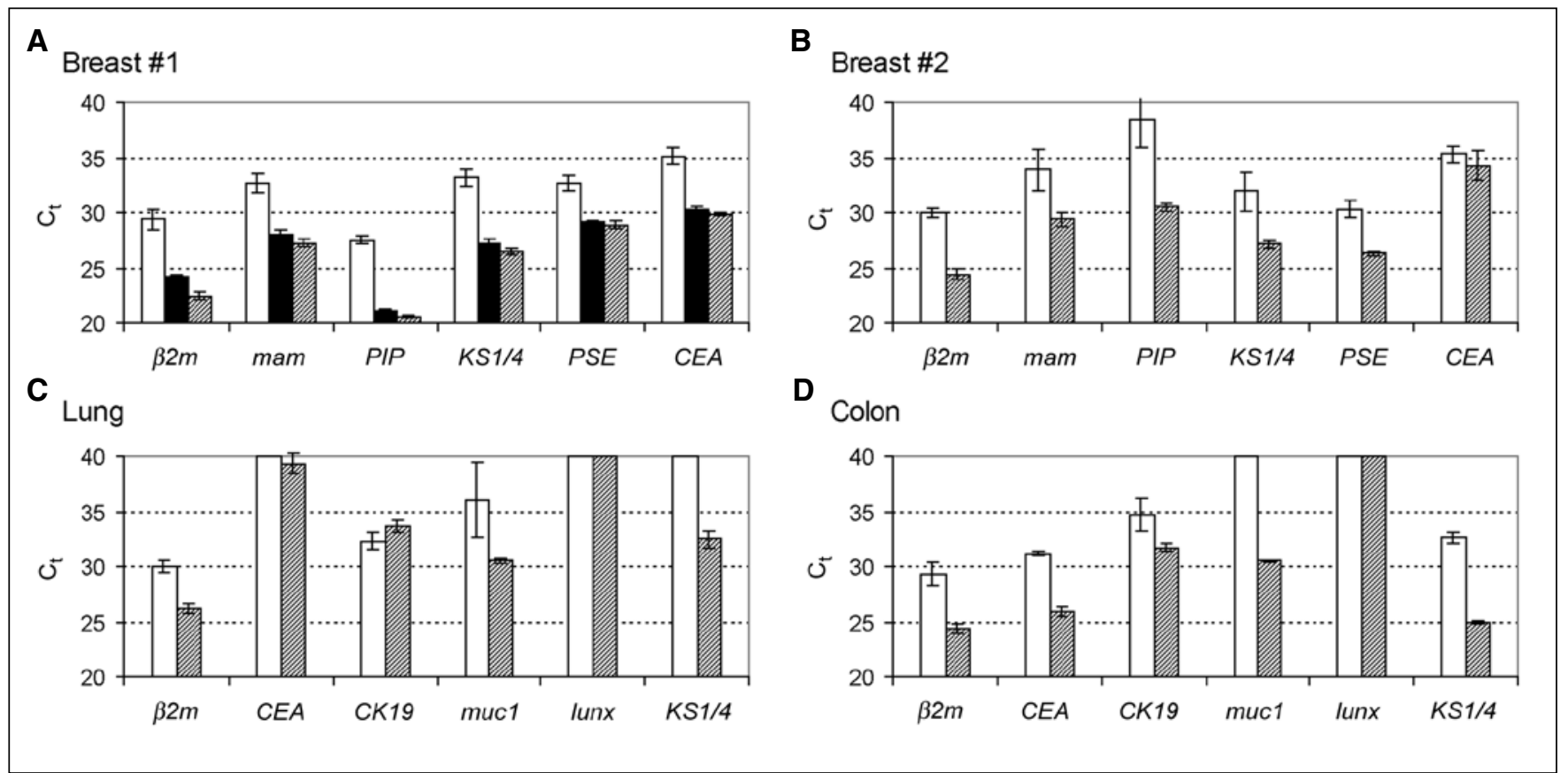

Figure 1. A panel of truncated gene-specific primers used in reverse transcription enhances gene detection in paraffin-embedded tissue (PET) samples. RNA from $80-\mu \mathrm{m}$ sections of formalin-fixed, paraffin-embedded breast (A and B), lung (C), and colon (D) cancer tissues was isolated and reverse-transcribed using either random hexamers (open bars), a single gene-specific primer ( $\beta 2 \mathrm{~m}$, mam, PIP, KS1/4, PSE, CEA; filled bars; panel A), or a panel of truncated genespecific primers (striped bars). PCR was performed using primers for genes indicated in the figure. Gene detection signals are expressed as cycle threshold $\left(\mathrm{C}_{\mathrm{t}}\right)$ values. The figure shows an average $\mathrm{C}_{\mathrm{t}}$ value of triplicate reactions $( \pm \mathrm{SD}) . \beta 2 \mathrm{~m}, \beta 2$-microglobin; mam, mammaglobin; $P I P$, prolactin-inducible protein; $K S 1 / 4$, epithelial cell adhesion molecule; PSE, prostate-specific Ets factor; CEA, carcinoembryonic antigen; muc 1, mucin 1; CK19, cytokeratin 19; lunx, lung-specific $\mathrm{X}$ protein.

tected using a panel of truncated genespecific primers. For example, $C E A$ and $K S 1 / 4$ in the paraffin-embedded lung tumor (Figure 1C), and mucl in colon tumor (Figure 1D) were not detected using reverse transcription with random hexamers, while priming with a panel of truncated gene-specific primers resulted in a detectable signal. Also, mucl in lung cancer (Figure 1C) and PIP in one of the breast cancer specimens (Figure 1B) were easily detected when a panel of truncated gene-specific primers was used, whereas priming with hexamers did not always result in signal detection. The lunx gene was not detected with either random hexamers or gene-specific primers.

The secondary aim of this study was to determine if a panel of truncated gene-specific primers is as effective as a single truncated gene-specific primer. Therefore, RNA from an 80- $\mu \mathrm{m}$ section of formalin-fixed, paraffin-embedded breast cancer tissue was isolated and reverse transcribed in separate reactions using either single truncated gene-specific primers $(\beta 2 \mathrm{~m}$, mam, PIP, KSI/4, $P S E$, or $C E A$ ) or a panel of truncated gene-specific primers containing all six primers. A reaction without reverse transcriptase was included as a negative control. For each reverse transcription reaction, real-time PCR was performed using specific forward and reverse primers. In this experiment (Figure 1A), we observed that reverse transcription with a panel of truncated gene-specific primers was comparable in efficiency to reverse transcription with single truncated gene-specific primers, supporting the approach of simultaneous reverse transcription for multiple genes.

In addition, the use of a panel of truncated gene-specific primers results in $C_{t}$ values from PET samples that are comparable to matched fresh-frozen samples (primary breast tumors, $n=8$, and metastatic axillary lymph nodes, $n$ $=12$; data not shown). Thus, the modification described in this report will facilitate the use of stored PET samples with known clinical outcome, opening an enormous resource for retrospective clinical studies to validate the use of diagnostic and/or prognostic genetic markers and to define the genetic pathogenesis of different diseases.

\section{ACKNOWLEDGMENTS}

We thank Dr. Jennifer Schnellmann for critical review of this manuscript. This work was supported by Small Business Innovation Research (SBIR) grant no. 1R43CA095534.

\section{REFERENCES}

1.Specht, K., T. Richter, U. Muller, A. Walch, M. Werner, and H. Hofler. 2001. Quantitative gene expression analysis in microdissected archival formalin-fixed and paraffinembedded tumor tissue. Am. J. Pathol. 158 419-429.

2.Masuda, N., T. Ohnishi, S. Kawamoto, M. Monden, and K. Okubo. 1999. Analysis of chemical modification of RNA from formalin-fixed samples and optimization of molecular biology applications for such samples. Nucleic Acids Res. 27:4436-4443.

3.Goldsworthy, S.M., P.S. Stockton, C.S. Trempus, J.F. Foley, and R.R. Maronpot. 1999. Effects of fixation on RNA extraction and amplification from laser capture microdissected tissue. Mol. Carcinog. 25:86-91.

4.Godfrey, T.E., S.H. Kim, M. Chavira, D.W. Ruff, R.S. Warren, J.W. Gray, and R.H. Jensen. 2000. Quantitative mRNA expression analysis from formalin-fixed, paraffin-embedded tissues using $5^{\prime}$ nuclease quantitative 
reverse transcription-polymerase chain reaction. J. Mol. Diagn. 2:84-91.

5.Coombs, N.J., A.C. Gough, and J.N. Primrose. 1999. Optimisation of DNA and RNA extraction from archival formalin-fixed tissue. Nucleic Acids Res. 27:e12.

6.Korbler, T., M. Grskovic, M. Dominis, and M. Antica. 2003. A simple method for RNA isolation from formalin-fixed and paraffin-embedded lymphatic tissues. Exp. Mol. Pathol. 74:336-340.

7.Stanta, G. and C. Schneider. 1991. RNA extracted from paraffin-embedded human tissues is amenable to analysis by PCR amplification. BioTechniques 11:304-308.

8.Corey, E. and M.J. Corey. 1998. Detection of disseminated prostate cells by reverse transcription-polymerase chain reaction (RTPCR): technical and clinical aspects. Int. J. Cancer 77:655-673.

9.Dennis, P., E.A. Edwards, S.N. Liss, and R. Fulthorpe. 2003. Monitoring gene expression in mixed microbial communities by using DNA microarrays. Appl. Environ. Microbiol. 69:769-778

10.Baker, M.K., K. Mikhitarian, W. Osta, K. Callahan, R. Hoda, F. Brescia, R. Kneuper-Hall, M. Mitas, et al. 2003. Molecular detection of breast cancer cells in the peripheral blood of advanced-stage breast cancer patients using multimarker real-time reverse transcription-polymerase chain reaction and a novel porous barrier density gradient centrifugation technology. Clin. Cancer Res. 9: 4865-4871.

11.Mitas, M., K. Mikhitarian, C. Walters, P.L. Baron, B.M. Elliott, T.E. Brothers, J.G. Robison, J.S. Metcalf, et al. 2001. Quantitative real-time RT-PCR detection of breast cancer micrometastasis using a multigene marker panel. Int. J. Cancer 93:162-171.

12.Mitas, M., D.J. Cole, L. Hoover, M.M. Fraig, K. Mikhitarian, M.I. Block, B.J. Hoffman, R.H. Hawes, et al. 2003. Realtime reverse transcription-PCR detects KS1/4 mRNA in mediastinal lymph nodes from patients with non-small cell lung cancer. Clin. Chem. 49:312-315.

13.Mitas, M., K. Mikhitarian, L. Hoover, M.A. Lockett, L. Kelley, A. Hill, W.E. Gillanders, and D.J. Cole. 2002. Prostate-Specific Ets (PSE) factor: a novel marker for detection of metastatic breast cancer in axillary lymph nodes. Br. J. Cancer 86:899-904.

14.Mitas, M., L. Hoover, G. Silvestri, C. Reed, M. Green, A.T. Turrisi, C. Sherman, K. Mikhitarian, et al. 2003. Lunx is a superior molecular marker for detection of non-small lung cell cancer in peripheral blood. J. Mol. Diagn. 5:237-242.
Received 17 November 2003; accepted 18 December 2003.

Address correspondence to Kaidi Mikhitarian, Medical University of South Carolina, 96 Jonathan Lucas Street, Suite 420, P.O. Box 250613, Charleston, SC 29425, USA. e-mail:mikhitar@musc.edu 